\title{
Transgenic aspens (Populus tremula) with the xyloglucanase gene from Penicillium canescens keep faster growth under semi-natural conditions
}

Elena O. Vidyagina

Institute if Bioorganic Chemistry

Natalia M. Subbotina

Institute of Bioorganic Chemistry

Vladimir A. Belyi

Institute of Chemistry

Vadim G. Lebedev

Institute of Bioorganic Chemistry

Konstantin V. Krutovsky ( $\square$ kkrutov@gwdg.de )

Georg-August-Universitat Gottingen https://orcid.org/0000-0002-8819-7084

Konstantin A. Shestibratov

Institute of Bioorganic Chemistry

Research article

Keywords: Aspen, Growth, Xyloglucanase, Penicillium canescens, Populus tremula, Transgenic

Posted Date: February 13th, 2020

DOI: https://doi.org/10.21203/rs.2.13781/v2

License: (c) (i) This work is licensed under a Creative Commons Attribution 4.0 International License.

Read Full License

Version of Record: A version of this preprint was published at BMC Plant Biology on June 3rd, 2020. See the published version at https://doi.org/10.1186/s12870-020-02469-2. 


\section{Abstract}

Background Recombinant carbohydrases genes are used to produce transgenic woody plants with improved phenotypic traits. However, cultivation of such plants in open field is challenged by a number of problems. Therefore, additional research is needed to alleviate them.

Results Results of successful cultivation of the transgenic aspens (Populus tremula) carrying the recombinant xyloglucanase gene (sp-Xeg) from Penicillium canescens in semi-natural conditions are reported in this paper for the first time. Change of carbohydrate composition of wood was observed in transgenic aspens carrying the sp-Xeg gene. The transformed transgenic line PtXVXeg1b demonstrated accelerated growth and increased content of cellulose in wood of trees growing in both greenhouse and outside in comparison with the control untransformed line Pt. The accelerated growth was observed also in the transgenic line PtXIVXeg1c. Thicker cell-wall and longer xylem fiber were also observed in both these transgenic lines. Undescribed earlier considerable reduction in the wood decomposition rate of the transgenic aspen stems was also revealed for the transformed transgenic lines. The decomposition rate was approximately twice as lower for the transgenic line PtXVXeg3b in comparison with the control untransformedline Pt.

Conclusion Our results showed that the plants carrying the recombinant sp-Xeg gene do not demonstrate a decrease in growth parameters in semi-natural conditions. However, in some transgenic lines, a change in the carbohydrate composition of the wood, an increase in the cell wall thickness and a decrease in the rate of decomposition of wood are observed.

\section{Background}

Forests play a huge role in the economy as a source of timber and many types of raw materials. The logging is growing every year worldwide [1]. Hardwood trees are of particular interest due to a lower content of resins and lignins, making them a convenient source of raw materials for various industries [24]. Aspen (Populus tremula) is currently one of the most promising hardwood species, fast-growing, with a wide distribution range. Aspen wood is increasingly used in the pulp, paper, and viscose industries, and for container, oriented strand board, and bioethanol production [5]. However, with a current high rate of logging of hardwood species, especially aspen, a shortage of raw materials is expected. Therefore, it is necessary not only to increase the efficiency and rationality of the use of wood, but also to establish forest plantations with increased productivity based on the new and improved tree forms and varieties. Their creation by traditional breeding is a long and not very efficient process [6], while the genetic engineering approach is considered as one of the promising methods for obtaining trees with desired properties [7].

Increase in plant cell size is possible by enzymatic softening the cell wall followed by its expansion due to increased intracellular pressure [8]. Xyloglucan is involved in formation of a strong cellular framework, a plant cell wall hemicellulose polysaccharide that cross-links nearby cellulose microfibrils [9]. 
Accordingly, softening of the cell wall occurs through separation of microfibrils by enzymes that cleave xyloglucans and weaken the bond between microfibrils [10]. Xyloglucanase is one of these enzymes belonging to the carbohydrase group, which hydrolyses xyloglucans, weakening the cross-linking of cellulose microfibrils [8].

Currently, the overexpression of carbohydrases splitting xyloglucan is considered as a promising way of modifying the tree phenotype, increasing the productivity of woody plants and changing the composition and properties of wood. Shani et al. [11] produced transgenic aspen trees (Populus tremula) with an endoglucanase gene cel1 from Arabidopsis thaliana, which had significant phenotypic changes, such as increased plant height, leaf size, stem diameter and a higher percentage of cellulose and hemicellulose in comparison with the untransformed control under greenhouse conditions. However, the results of field trials were not reported. Park et al. [12] showed that in white poplar (Populus alba) transformed with the xyloglucanase gene AaXEG2 from Aspergillus aculeatus, increased length of stems and discoloration of leaves were observed in comparison with the control in the climatic chambers. There was also an increase in cellulose content and a reduction in hemicellulose in transgenic trees [12]. However, the growth rate of the transgenic trees in the field was lower than that of wild-type control trees [13].

The analysis of the world experience has shown that there are successful results in using of recombinant carbohydrases and xyloglucanases to increase the growth rate and improve the quality of aspen wood (genus Populus). However, not all issues in this area are completely solved, especially for trees grown in field conditions. Therefore, the aim of this work is to analyze aspen with altered properties of wood carrying the recombinant xyloglucanase $s p-X e g$ gene from Penicillium canescens under semi-natural conditions as a preliminary stage before the field trials.

This article reports successful tests of transgenic aspen trees carrying a recombinant xyloglucanase gene $s p-X e g$ and growing under semi-natural conditions. Effects of xyloglucanase gene incorporation on growth parameters, chemical wood composition and rate of wood decomposition are also presented and discussed.

\section{Results}

\section{Expression of xyloglucanase}

The expression of recombinant gene $s p-X e g$ in the plants growing in semi-natural conditions was confirmed by RT-PCR. The amplification product of the expected size (762 bp) was found in all transgenic lines with the inserted xyloglucanase gene taken for the analysis, which confirms the presence of transcripts of the recombinant $s p$-Xeg gene (Fig. 1).

Western blotting confirmed the presence of a recombinant XegA protein of the appropriate size (25 kDa) in the obtained 25 independent transgenic lines of aspen carrying the xyloglucanase gene $s p$-Xeg $[14,15]$. Fig. 2 shows the results of Western blotting for 10 of the 25 lines, in which the recombinant protein was detected stably in all replicates of the assay. 


\section{Growth rate}

Earlier, we noted that in a greenhouse environment, some transgenic lines showed an increase in the growth rate [15]. Transgenic and control plants of aspen were transferred from the greenhouse conditions to an open air and grown under semi-natural conditions up to the age of 18 months. For the analysis, six lines were chosen that demonstrated the presence of a recombinant protein. Four of them had an increased plants height in greenhouse conditions after two months in comparison with the Pt control line by $24.6 \%$ for the PtXIVXeg1a line, $15.7 \%$ for PtXIVXeg $1 b, 26.6 \%$ for PtXVXeg $1 b$ and $15.3 \%$ for PtXVXeg $3 b$. The other two lines (PtXIVXeg1c and PtXVXeg5a) were not different from the control [15]. It should also be mentioned that although a tendency in increased tree height was observed for most of the transgenic trees in semi-natural conditions, statistically significant increase in tree height, as well as in stem diameter and volume, was observed only for the PtXVXeg $1 b$ line (Table 1, Fig. 3). In the greenhouse, after two months of vegetation, this line was taller than non-transgenic Pt control by $26.6 \%$, in the open air after 6 months of vegetation by $25.4 \%$, and after 18 months by $14.6 \%$ (Fig. 4 ).

$<$ Table 1>

Integration of the xyloglucanase gene had little effect on the leaf area of transgenic plants. Only two aspen lines showed a significant decrease in area - PtXIVXeg $1 b$ by $28 \%$ and PtXVXeg $3 b$ by $17 \%$ compared to the control plants (Table 2).

$<$ Table 2>

However, almost all transgenic lines changed the leaf shape - they significantly reduced the circularity. This was due to an increase in the length and decrease in the width of the leaf blade of transgenic plants. As a result, all the transgenic lines significantly changed the length-to-width ratio of the leaf by $14-23 \%$ compared to the control plants (Fig. 5). For all transgenic plants, there was a tendency to increase the number of leaves, but not statistically significant (Table 1 ).

\section{Cellulose content in wood}

The content of cellulose was measured in wood of all six studied transgenic lines. A significant increase in cellulose content was observed only in the PtXIVXeg1c and PtXVXeg1b lines (Table 1). The content of cellulose in other lines was on average at the control level. The reduction of cellulose content in transgenic lines was not detected. Thus, in terms of cellulose content, the PtXIVXeg1c line can be also considered as a prospective line in addition to the PtXVXeg $1 \mathrm{~b}$ line. 


\section{Carbohydrate composition of xylem}

Xyloglucanase promotes cleavage of xyloglucan, thereby affecting the carbohydrate composition. A decrease in the content of pentosans (the main component of hemicellulose) was observed in all greenhouse plants [15]. In plants under semi-natural conditions, there was also a decrease in the content of pentosans in all transgenic lines in the youngest parts of the stem in comparison with control (Table 3). Less difference from control was observed in the older (18-month-old) parts of the stem, and four out of six lines demonstrated an increase in the content of pentosans. However, all changes were statistically insignificant.

$<$ Table 3>

The ratio of hemicellulose components was also affected in transgenic lines (Fig. 6). In the youngest parts of the plant, a significant decrease in the xylose content was observed in most of the lines, accompanied by an increase in the content of glucose and sometimes arabinose (Fig. 6a). The content of galactose and mannose varied insignificantly. In the most mature wood, the proportions of xylose and glucose did not differ significantly from control, but the content of arabinose and mannose was slightly, but significantly increased (Fig. 6b). The relative content of rhamnose and fucose in aspen wood was relatively low: $1.5-2 \%$ of rhamnose, independently of the wood age, and $0.2-0.5 \%$ and $0.1-0.2 \%$ of fucose in the younger and older wood, respectively.

\section{Libriform fiber analysis}

The diameter and length of the libriform fiber measured in wood samples of six studied lines are presented in Table 4. A slight increase in the fiber diameter was observed in transgenic plants. The fiber length was significantly higher than in the control in two lines PtXVXeg1b and PtXVXeg3b. (Table 4).

$<$ Table 4>

\section{Microscopy of xylem}

Electron microscopy of xylem of 18-month-old aspen showed an increase of the cell wall thickness in prospective lines PtXVXeg1b (1.80 microns on average) and PtXIVXeg1c (1.47 microns on average) in the xylem cells of the first year of vegetation in comparison with non-transgenic control (1.16 microns) (Fig. 7). 


\section{Decomposition rate}

Transgenic lines PtXIVXeg $1 b$ and PtXVXeg $3 b$ and control Pt were used in the decomposition experiment. These two transgenic lines were the most morphologically and biochemically similar to Pt. Analysis of the carbon dioxide emission during the decomposition of plant material showed that the stems of transgenic plants had a decomposition rate lower than in the control, especially for PtXVXeg3b, where it was about two times slower than in the control line Pt (Fig. 8). However, during root decomposition no significant difference in the carbon dioxide emission was detected between transgenic and control plants.

A significant decrease of nitrogen was observed in stems of transgenic plants in comparison with the control line, while no change for nitrogen was found in the roots. No change for carbon was found in both roots and stems of the transgenic lines in comparison with the control line (Table 5).

$<$ Table 5>

\section{Discussion}

Studies of the effect of the introduced recombinant construct in transgenic woody plants are usually based on a small sample of the analyzed lines selected from the entire panel of generated transgenic lines. Therefore, it is typical that only six out of 25 transgenic lines were selected for further analysis in open ground conditions in our study. For instance, in a similar study of the recombinant GS1 gene expression in poplar hybrids (Populus tremula $\times$ P. alba), only eight transgenic lines were analyzed in field trials [17] selected from 22 initially generated transgenic lines that were grown first under greenhouse conditions [16]. Moreover, a detailed study of the recombinant gene was based only on one line [18]. In another similar study of the PIP1 aquaporin gene the initial panel of PIP1-deficient transgenic Populus tremula $x$ alba poplar hybrids included 22 lines, but only six lines were selected for initial tests in the greenhouse [19], and then five of them were selected for the detailed study [20]. In the initial study of the isoprene synthase gene ISPS 29 transgenic Grey poplar (Populus $\times$ canescens) lines were generated [21], but only one line was used in the further semi-natural studies [22]. Therefore, following the common practice in the analysis of transgenic woody plants, six from 25 transgenic greenhouse lines generated in our previous study [15] were selected for this study under semi-natural conditions.

The creation of highly productive woody plants with altered wood properties by increasing the cleavage of xyloglucan was considered in some studies as the most promising direction [12, 23]. However, successful results obtained in climatic chambers and greenhouse were not always confirmed in the field [13]. We tested our transgenic aspen lines with recombinant $s p-X e g$ gene also under semi-natural conditions: they had a closed root system and were grown in an open air during the entire vegetation period. The increase of height is considered as the main indicator of rapid growth in many similar studies related to selection for the faster growing plants $[11,12,18,24]$. Measurements of their heights demonstrated that not all of the previously identified promising lines [15] have maintained a higher plant 
height. Convergence of phenotypic traits between transgenic and control lines was observed. PtXVXeg1b was the only line that maintained a high degree of productivity throughout the studies compared to the control. The increase in growth rate of the PtXVXeg $1 b$ line was relatively high in comparison with data published by other researchers [12]. Transgenic white poplars with xyloglucanase from $A$. aculeatus also tended to increase growth rates, but they were grown in climatic chambers [12]. When these plants were grown under greenhouse conditions, no difference in the growth rate was found [25]. Further field trials of these transgenic poplar plants showed that two transgenic white poplar lines trg300-1 and trg300-2 with overexpression of recombinant xyloglucanase from the fungus $A$. aculeatus showed a decrease in the growth rate and total biomass compared with non-transgenic control, while previously demonstrated an increase in productivity in climatic chambers. It was found that the deterioration in growth rates was due to a change in the transpiration process. In transgenic plants stomata dysfunction was observed [13]. The xyloglucanase $X e g A$, which we used, is structurally identical to xyloglucanase from $A$. aculeatus (AaXEG2) at $70.46 \%$ based on the data from the NCBI database. Therefore, similar effects of the recombinant xyloglucanase $X e g A$ and xyloglucanase $A a X E G 2$ on plants were observed. The transgenic plants of the line PtXVXeg1 b obtained by us maintained the tendency to increase the growth rate in all experimental conditions. It was observed that incorporation of hormonal control or transcription factor genes can affect the size of plant organs [26]. A similar effect was observed in aspens with xyloglucanase gene in our study. We observed the change in a leaf shape in all transgenic lines - the ratio of length to width increased, mainly due to a decrease in the leaf width (Table 3). The final size of plant organs, such as leaves, is controlled by two processes - cell division and cell expansion [27]. The size change can occur not in both, but only in the one dimension. For instance, the overexpression of the cytochrome P450 gene in Arabidopsis increased the length of the leaves without any change of their width [28]. Reducing leaf size is possibly associated with a decrease in the number and / or size of cells [29]. We found that a significant increase in the length of the wood fiber was observed in transgenic lines without any change in diameter (Table 4). Since xyloglucan is involved in changing the cell shape in growth and differentiation zones [30], the expression of the xyloglucanase gene could also alter the wall extensibility in the leaf cells, which changed the shape of the cells and subsequently the leaf shape. Moreover, the observed in our study tendency of increasing the number of leaves in transgenic plants may have a compensatory effect on the growth characteristics of these plants [15].

The main structural motif of xyloglucan in genus Populus is a repeating block of the XXXG type consisting of three glucose residues containing the xylose substituent $(X)$ and one unsubstituted glucose residue $(G)$ [31]. In the two-year-old wood of the control aspens, the content was quite similar to this indicator, both in absolute values and in the ratio of xylose, 3.6. However, in young areas the ratio was sharply reduced to 1.8 , because xylose decreased and cellulose increased simultaneously at the same time. The incorporation of the xyloglucanase gene has altered the composition of the polysaccharide matrix, which primarily resulted in an increase in glucose and a decrease in xylose that caused defects in the formation of xylan. It was most significant in young plants, but was also observed in more mature wood, although to a lesser extent (most significantly in the PtXIVXeg1a and PtXIVXeg1b lines). This suggests that the incorporation of the xyloglucanase gene promoted the formation of hemicellulose, 
which is characteristic of the earlier stage of plant development. In the more mature wood, the effect of the xyloglucanase gene was minimal - the content of the main components did not differ much from the control, although the share of the minor components - mannose and arabinose - increased slightly. The third component, galactose, practically did not change. However, we noted significant changes in the relative content of other hemicellulose polysaccharides, which may be due to an indirect effect on the biosynthesis of the secondary cell wall. Our data partially agree with the results of Baba et al. [32], according to which $10 \%$ decrease in polysaccharide matrix was noted in the poplar with xyloglucanase gene, as well as a slight decrease in xylose due to galactose and arabinose. Unfortunately, in this work the age of plants was not specified. A significant decrease in xylose was observed in all Populus deltoides lines with suppression of the glycosyltransferase gene by interfering RNA [33], where it occurred due to galactose and mannose, but the glucose did not change. The reverse effect was in Populus euramericana with interfering RNA on endoglucanase gene, where xylose increased substantially, and glucose was reduced, while other hemicellulose sugars - mannose, galactose, arabinose, rhamnose and fucose remained unchanged [34]. We found that the incorporation of the xyloglucanase gene in our transgenic aspens led to a decrease in the content of hemicellulose in young wood. In addition, the gene xyloglucanase has changed the composition of xyloglucan, making it more characteristic for an early age. We also showed that this effect is weakened with the age of the plant, and it is practically absent in the second year wood. It is possible that compensatory mechanisms for the formation of hemicellulose are amplified with age, and, in addition, it could be promoted by our plants being grown under seminatural conditions.

It was demonstrated earlier that the cellulose formation can indirectly affect the binding of microfibrils to each other by xyloglucan filaments, and, therefore, the cleavage of which can probably have a stimulating effect on the cellulose biosynthesis [35]. Our plants had an increase in the cellulose content by $7.4 \%$ and $11.3 \%$ in the lines PtXVXeg1b and PtXIVXeg1c, respectively. Our cellulose content data are in consensus with the data on electron microscopy of xylem of transgenic plants, as well as with the data on libriform measurement. The length of the fibers has increased in some transgenic lines. This is due to the specific interaction of xyloglucanases with the cell walls resulted to the separation of the cellulose microfibrils that led to the cell size increase due to the increase of intracellular pressure [8]. An increase in the cellulose content may be associated with an increase in the thickness of the cell walls, especially if the gelatinous layer increases [36]. We noted that the thickness of the cell wall of xylem in transgenic plants exceeded the control values and averaged 1.63 microns, whereas in control plants it was 1.16 microns. This is comparable to the increase in cellulose content in these plants.

Changes in the wood composition can affect also biogeochemical processes in ecosystems. In our earlier studies, we measured the decomposition rate of aspen wood in lines with the xyloglucanase gene using the method of mass loss [37]. Significant differences in the decomposition rate between transgenic and control plants were found at the early stages in the transgenic roots, but not in stems. However, this method is not accurate enough, since it does not take into account the coefficient of microbial conversion, which includes the increase in the biomass of microorganisms during decomposition [38]. For a more accurate determination of the decomposition rate in plants, it is recommended to measure the 
intensity of the $\mathrm{CO}_{2}$ emission [39]. In our study we used this method in stems and roots, which are rarely used both in decomposition experiments. According to Zhang et al. [40], the overwhelming number of decomposition experiments were conducted with leaves or needles, and branches and roots are only occasionally used. Meanwhile, leaves and roots constitute a significant proportion of annual litter, and the built-in gene has an effect on the composition of the wood. Although our main experiment was conducted for two years, we used 6-month-old samples to study decomposition because they better represent the structure of litter in the natural conditions. According to Freschet et al. [41], 41\% of the annual forest litter consists of leaves, $11 \%$ of the branches with up to $5 \mathrm{~mm}$ in diameter and $48 \%$ of the roots with up to $2 \mathrm{~mm}$ in diameter.

Measurement of the intensity of the $\mathrm{CO}_{2}$ emission showed that for wood of stems of transgenic plants, a significant decrease in the rate of decomposition is characteristic. Such a change may be due to a decrease in the nitrogen content of these plants by $15 \%$ on average. A number of studies reported that the nitrogen content was directly related to the decomposition rate of plant residues $[40,42,43]$. The higher nitrogen content increased the rate of decomposition, and the lower content reduced it. Perhaps, for the same reason, differences in the emission of carbon dioxide during the decomposition of the roots of our transgenic plants were not detected. It is likely that an increase in the thickness of the cell wall can also affect the rate of wood decomposition [44].

Our analysis of six transgenic lines under semi-natural conditions showed that the effect of the recombinant gene is observed in all transgenic lines. Thus, based on the results of the aspen tests in semi-natural conditions, it can be concluded that the recombinant $s p$-Xeg gene has a complex effect on the plant organism. Recombinant gene influenced not only the growth parameters of transgenic plants, but also the content of cellulose, plant fiber, and decomposition rate of wood. Among all transgenic aspen lines with the $s p$-Xeg gene, PtXVXeg1b was identified as the most promising line, which under all test conditions maintained an increased growth rate, had a higher cellulose content and a thicker cell wall of xylem fibers. According to the published studies for woody plants, it is typical that researchers focus on detail study of recombinant gene effects in semi-natural and field trials only in a one or a few transgenic lines $[18,20,22]$. We confirmed fast-growing only in one line, but it has a great practical value. Moreover, it supports further study of other remaining lines that may also contain lines fast-growing under semi-natural cultivation conditions.

Modification of plant properties through genetic transformation should always be assessed for its environmental impact. In particular, how transgenic aspen can affect forest ecosystems and soil. A computer simulation of virtual forest plantations consisted of the PtXVXeg 1 b clone and non-transgenic plants was carried out earlier using the EFIMOD simulation model that can predict carbon and nitrogen flows in forest ecosystems with strong feedback mechanism between soil and stand [45]. This model experiment showed that effect of growing transgenic aspens on carbon and nitrogen flows was not different from effect of non-transgenic plants in controls.

\section{Conclusions}


The representative panel of transgenic aspen lines with the constitutive expression of recombinant xyloglucanase gene $s p-X e g$ from Penicillium canescens was analyzed. It was proved that the expression of $s p$-Xeg recombinant xyloglucanase leads to a change of thickness of wood fiber and the plant growth. Electron microscopy showed an increase in cell wall thickness in transgenic lines. Libriform analysis also showed an increase in the length and width of the vascular fiber in transgenic plants. An increase in wood fiber parameters is likely to affect growth. For the first time, it was shown that transgenic aspen plants with the gene of recombinant xyloglucanase of fungal origin under test conditions close to the field (semi-natural conditions) do not demonstrate growth reduction. In transgenic plants, $s p$-Xeg recombinant xyloglucanase alters the composition of carbohydrate-containing substances in wood. The change in the content of cellulose and hemicellulose is confirmed by the data obtained in the analysis of the xylem monomeric sugars composition. For the first time, an analysis of carbon dioxide emissions during the decomposition of plant material was carried out. It showed that the stems of transgenic plants had a decomposition rate lower than the control ones.

This is a preliminary study based on a relatively small panel of the obtained transgenic lines. Although this study is in agreement with many similar studies of transgenic woody plants based also on a small number of transgenic lines selected from a larger panel of generated transgenes (e.g., [17, 19, 24]), we believe that more studies are needed. However, the presented here study has generated important practical data regarding performance of transgenic lines in open ground conditions (semi-natural and field cultivation conditions) and effects of recombinant xyloglucanase sp-Xeg affecting not only productivity, but also other parameters. This study supports the trend in the action of recombinant xyloglucanase sp-Xeg observed earlier in greenhouse conditions [15]. We plan to continue monitoring field trials with six selected transgenic lines, as well as to analyze the remaining lines under semi-natural cultivation conditions.

\section{Methods}

\section{Transgenic aspens}

Transgenic aspen lines with the introduced recombinant $s p$-Xeg xyloglucanase gene from the fungus Penicillium canescens under the transcriptional control of the 35S promoter and nopaline synthase terminator were analyzed. The $s p$-Xeg gene encodes a chimeric xyloglucanase $X e g A$ with a white poplar cellulase signal peptide [14]. The in vitro-derived trees were adapted to in vivo conditions in the climatic chambers for a month and were grown in greenhouses for a further month. In total, 25 transgenic lines, two control lines - non-transgenic wild-type line $(P t)$ and a transgenic line with the inserted gene $\beta$ glucuronidase (Pt/Gus5a) were studied, respectively. Each line (genotype) was represented by 50 plants (ramets). The plants were grown in individual plastic containers with a volume of 1 liter (with peat to perlite ratio of 3:1) and after two months of growth in the greenhouse moved to semi-natural conditions in an open air with additional watering and feeding. Semi-natural conditions are the cultivation of potted plants outside of the greenhouse [46]. Such growing conditions are close to the field and allow us to estimate the resistance of plants to various biotic and abiotic factors. After four months of vegetation 
under semi-natural conditions, a random sample of six transgenic lines and a non-transgenic control line $(P t)$ were selected for the further analysis. Selected lines were transplanted into plastic containers with a volume of 2 liters. Nontransgenic control aspens (natural variant) were randomized with aspens of transgenic lines and grown together alongside each other under the same conditions. Under these conditions the plants were grown up to the age of one and a half years with wintering in natural conditions.

After two months of growth in the greenhouse and before transfer to semi-natural conditions, the height and number of leaves were measured. After another 4 months of vegetation, growth was measured, samples were taken for molecular analyses and carbohydrate composition measurement, and some of the plants were used to analyze the decomposition rate of the stem wood. The second part wintered and continued to grow for another year, and then, at the age of 18 months, the growth, content of cellulose and pentosans were measured, and samples were taken for carbohydrate composition, microscopy and libriform, and the annual results of the decomposition experiment were evaluated.

The presence of the recombinant gene and protein expression were confirmed in all 25 transgenic lines. Following common practice used in studies of transgenic woody plants we selected six transgenic lines from 25 previously transformed greenhouse plants for our analysis under semi-natural conditions [15]. The sampling was random (except excluding abnormally developing dwarf line PtXVXeg1c). This subsample included PtXIVXeg1a, PtXIVXeg1b, PtXIVXeg1c, PtXVXeg1b, PtXVXeg3b, and PtXVXeg5a. Four of them demonstrated increased growth in comparison with the control line $(P t)$, but only for one line (PtXVXeg1b) it was statistically significant (Table 1). In addition to growth parameters, analyses of specific content of cellulose, pentosans, carbohydrate composition of xylem, measurement of libriform were also performed on all these six transgenic lines and the control line. Electron microscopy was carried out on the plants of the PtXIVXeg1c, PtXVXeg1b, and Pt lines. The decomposition rate was measured in the plants of the PtXIVXeg $1 b, P t X V X e g 3 b$ and Pt lines. To carry out the decomposition analysis, we selected these two lines that fell into the same group with the control plants according to Duncan's ANOVA-1 rank tests based on measuring biometric indicators obtained for greenhouse plants, and they differed only by the content of pentosans [15].

\section{RT-PCR analysis}

Total plant RNA was extracted from the leaves of all 6-month-old transgenic and control lines collected in the semi-natural conditions by the Invitrogen commercial method with the TRIzol ${ }^{\circledR}$ reagent (Thermo Fisher Scientific Inc., USA). Genomic DNA was removed from the samples using DNAse I (Fermentas, USA) according to the manufacturer's protocol. cDNA synthesis was performed using M-MuLV reverse transcriptase, RNaseH- (SibEnzyme, Russia) and oligo-d(T)18 primer (Synthol, Russia) at a temperature of $37^{\circ} \mathrm{C}$ for 75 minutes. For the revertase inactivation, the mixture was heated to $70^{\circ} \mathrm{C}$. We took $2 \mu \mathrm{l}$ of the cDNA mixture as a template for PCR amplification using primers Xeg-up (GAAATGGCTAATGCCACTACATT) and Xeg-low (GATTTAGGCAACATCGGCAG) (Evrogen, Russia) under conditions similar to the PCR analysis of total DNA [15]. To control RNA contamination with residues of 
the genomic DNA, PCR was performed with RNA preparations of each of the clones without revertase treatment.

\section{Western blot analysis}

Total protein extracts were obtained from the leaves of 6-month-old transgenic and control plants ex vitro by the addition of an extraction buffer [0.175 M Tris / HCl (pH 8.8), $5 \%$ SDS (w/v), $15 \%$ glycerol (v/v), $0.3 \mathrm{M}$ mercaptoethanol] [47]. Electrophoretic separation of proteins was performed according to Laemmli [48] in a $12 \%$ polyacrylamide gel. Electrotransfer of the separated polypeptides was carried out on a BioTrace nitrocellulose membrane (Pall, USA) by semi-dry transfer on a TE70PWR transblotter (Amersham, USA). Polyclonal rabbit anti-xyloglucanase antibodies from $P$. canescens fungus were used as the primary antibodies. Monoclonal goat anti-rabbit antibodies conjugated with alkaline phosphatase (Sigma, USA) were used as the secondary antibodies. Immunocomplexes were detected using a stabilized Western Blue substrate (Promega, USA). It was a qualitative Western blot analysis.

\section{Growth indicators}

To study each line, 40 plants were used. The length of the stem was measured from the root neck to the apical bud. Stem diameter was measured at the base of the root neck. The volume $\left(V, \mathrm{~cm}^{3}\right)$ was measured by the formula: $V=S D^{2} H$, where SD - stem diameter (cm), $H$ - plant height (cm) [11]. The number of leaves was calculated from the apical bud and to the root neck. The parameters of the leaf blade were measured using the LAMINA software [49] in the second year of vegetation. Height was measured at the age of 2, 6 and 18 months and analyzed using the Statistica 7.0 software (https://www.tibco.com/products/tibco-statistica).

\section{Analysis of the specific cellulose content}

Median internodes of 20 plants per each 18-month-old line were used to determine the content of cellulose by the Kurschner-Hanak nitrogen-alcohol method [50]. The content was recalculated taking into account the weight of an absolutely dry sample.

\section{Analysis of the specific pentosan content}

The specific content of pentosans in wood was estimated using the modified Tollens method [51, 52] by converting them to furfural during distillation in the presence of $\mathrm{HCl}$. For this analysis, two $10 \mathrm{~cm}$ long cuts of stem per plant, representing the 1 st and the 2 nd year growing wood, respectively, were taken from 18-month-old plants. The cuts were stripped off their bark, and the air-dried sawdust samples weighing $0.1 \mathrm{~g}$ were prepared. The optical absorption of the distillate was measured by a two-beam spectrophotometer at a wavelength of $277 \mathrm{~nm}$. The dryness coefficient of wood $\left(\mathrm{C}_{\text {dry }}\right)$ was calculated from the following formulas: $d r y$ where $W$ - the relative humidity of the wood, $m$ - the mass of the empty bag $(g), \mathrm{m} 1$ and $\mathrm{m} 2$ - the weights $(g)$ of the bag with the sample before and after drying, respectively. Then, the content of pentosans in dry matter was calculated according to the formula: , where $A-$ the 
percentage of pentosans in the air-dry sample, D - the average optical absorption of the furfural solution obtained from the distillation, $\mathrm{n}$ - the conversion factor for the percentage of furfural to pentosans $(2.434$ for hardwoods), $\mathrm{m}$ - the mass of the sawdust sample $(g), \mathrm{C}_{\text {dry }}$ - coefficient of dryness. For clarity, the percentage of pentosans was converted to absolute values as $m g / g$ dry weight.

\section{Analysis of hemicelluloses monosaccharide}

Monomeric sugars of hemicelluloses (arabinose, fucose, galactose, glucose, mannose, rhamnose, and xylose) were measured by standard alditol acetate method $[53,54]$. For the analysis of the composition of monosaccharides, two $10 \mathrm{~cm}$ long cuts of stem per plant without bark, representing the $1 \mathrm{st}$ (6 months) and the 2nd (18 months) year growing wood, respectively, were taken from 18-month-old plants. Samples of $5 \mathrm{mg}$ of wood sawdust were hydrolyzed with $2 \mathrm{M}$ trifluoroacetic acid (TFA) at $100^{\circ} \mathrm{C}$ for 5 hours. The mixture of neutral monosaccharides was converted to alditol acetates and identified by gas chromatography-mass spectrometry (GC-MS) analysis using the GCMSQP 2010 Plus chromatograph (Shimadzu Corporation, Japan) with the HP-5MS column (60 $m \times 0.32 \mathrm{~mm} \times 0.25 \mu \mathrm{m})$. Myo-inositol was used as an internal standard. Helium was used as the carrier gas. The temperature of the injector was $150^{\circ} \mathrm{C}$. The column temperature was increased from $60^{\circ} \mathrm{C}$ to $250^{\circ} \mathrm{C}$ at a rate of $2^{\circ} \mathrm{C} / \mathrm{min}$, and, then, held for 10 minutes [55].

\section{Microscopy}

For the microscopy analysis, samples of 18-month-old plants were taken from the lower part of the stem (wood of the second year of cultivation) in three replicates. A total cut of all tissues of the stem was made. To prepare the cross sections, the samples were embedded in the epoxy-resin mixture containing DER-332, DER-732, DDSA, and DMP-30 [56]. The transverse sections were obtained using the ultra microtome Reichert Om U2 (Austria) with glass knives, stained with methylene blue, azur-II, and basic fuchsin [57] and photographed with the Axiolmager M1 light microscope (CarlZeiss, Germany). The slices were scanned, and the thickness of the cell walls was estimated using the AxioVision 4.8.1 software package (CarlZeiss, Germany).

\section{Measurement of the libriform fibers}

For the measurement of the libriform fibers, samples of the 18-month-old plants were taken from the bottom of the stem without bark (wood of the second year of cultivation) in three replicates. Samples were macerated using acetic acid and sodium chlorite, and the length and diameter of their libriform fibers were measured [58].

\section{Measurement of the aspen decomposition rate}

The decomposition rate was estimated by analyzing the emission of carbon dioxide during plant material decomposition [59]. In the experiment, sifted through a $0.5 \mathrm{~mm}$ fine sieve, washed and sterilized sand was used as a substrate. The plant tissue (stems and roots) from the 6-month-old plants was ground in a 
porcelain mortar, and, then, dried at $65^{\circ} \mathrm{C}$ for three days, and $100 \mathrm{mg}$ of this dried and ground tissue were placed in a glass tube with $2 \mathrm{~g}$ of sand and sealed with rubber stoppers. To ensure the decomposition in the test tubes, an aqueous extract of the forest plant litter was added. Distilled water was also added to the tubes in an amount of $50 \%$ of the total moisture capacity of the sand (taking also into account the water needed to restore the initial mass of plant tissue). Then, the tubes were placed in a thermostat at $22^{\circ} \mathrm{C}$ for 48 weeks. Samples of air were sampled from the tubes every 8 weeks, and their carbon dioxide gas was analyzed using a gas chromatograph Crystallux 4000M (Research and Production Company «Meta-chrom», Yoshkar-Ola, Russia). All samples were analyzed also for $\mathrm{C}$ and $\mathrm{N}$ content by gas chromatography using the Euro EA-CHNSO Elemental Analyser (HEKAtech GmbH, Wegberg, Germany).

\section{Abbreviations}

AaXEG2: xyloglucanase 2 from Aspergillus aculeatus; ANOVA: analysis of variance; bp: base pair; cDNA: complementary DNA; cel1: cellulase gene 1; DNA: deoxyribonucleic acid; DNase: deoxyribonuclease; GCMS: gas chromatography-mass spectrometry; GS1: glutamine synthetase 1; ISPS. isoprene synthase; kDa: kilodalton; P. probability; PCR: polymerase chain reaction; PIP1: aquaporin 1; Pt. Populus tremula; RNA: ribonucleic acid; RNase: ribonuclease; RT-PCR: reverse transcription polymerase chain reaction; SD: standard deviation; SDS: sodium dodecyl sulfate; $s p$-Xeg. recombinant xyloglucanase from Penicillium canescens; TFA: trifluoroacetic acid; Tris: tris(hydroxymethyl)-aminomethan; Xeg: xyloglucanase.

\section{Declarations}

\section{Ethics approval and consent to participate}

Not applicable

\section{Consent for publication}

Not applicable

\section{Availability of data and materials}

The datasets used and/or analyzed during the current study are available from the corresponding author upon request.

\section{Competing interests}

The authors declare that they have no competing interests.

\section{Funding}

This work including the study and collection, analysis and interpretation of data, and writing the manuscript was supported by research grant № 0101-2019-0037 from Ministry of Science and High 
Education of the Russian Federation within the state program "Plant molecular biology and biotechnology: their cultivation, pathogen and stress protection (BIBCH)".

\section{Author contributions}

EOV, VGL, and KAS conceived the study and designed the experiments. EOV, NMS, VAB, and VGL carried out the experiments and analyzed the data. KAS acquired funds, supervised and administered the study. KVK provided scientific support and consultation. EOV drafted the manuscript. EOV, VGL, KVK, and KAS revised the manuscript. All authors read and approved the final version of the submitted manuscript.

\section{Acknowledgments}

Authors are thankful to the editor and two anonymous reviewers for their suggestions that helped us improve the manuscript.

\section{References}

1. Carle J, Holmgren P. Wood from planted forests: a global outlook 2005-2030. Forest Prod J. 2008;58:6-18.

2. Azarov VI, Burov AV, Obolenskaya A.V. Chemistry of wood and synthetic polymers. Saint-Petersburg Forestry Academy, St. Petersburg, Russian Federation; 1999. 629 p.

3. Jonsson R, Egnell G, BaudinA. Swedish Forest Sector Outlook. Future Forests Working Report, Department of Swedish Forestry; 2011.

4. Bosbeer S, Denman H, Hawe JD, Purser HP, Walsh P. Review of forest policy for the heritage council. An Chomhairle Oidhreachta. The Heritage Council;

5. Friesen MW. A strategic analysis for aspen solid wood products in Saskatchewan. FPInnovations, Vancouver, British Columbia, Canada; 2011:2-24.

6. Chaix G, Monteuuis O. Biotechnology in the forestry sector. Preliminary review of biotechnology in forestry, including genetic modification. Forest Genetic Resources Working Paper FGR/59E. Forest Resources Development Service, Forest Resources Division: Rome, Italy; 2004:116-8.

7. Costanza MS. Forest biotechnology and its responsible use: a biotech tree primer by the Institute of Forest Biotechnology. Institute of Forest Biotechnology, Raleigh, NC, USA; 2011.

8. Mellerowicz E, Immerzeel P, Hayashi T. Xyloglucan: the molecular muscle of trees. Annals of Botany. 2008;102(5):659-65.

9. Bauman MJ, Eklo G, Michel M, Kallas AM, Teeri TT, Czjzek M, Brumer H. Structural evidence for the evolution of xyloglucanase activity from xyloglucan endo-transglycosylases: biological implications for cell wall metabolism. Plant Cell. 2007;19:1947-63.

10. Takeda T, Furuta Y, Awano T, Mizuno K, Mitsuishi Y, Hayashi T. Suppression and acceleration of cell elongation by integration of xyloglucans in pea stem segments. Proc Natl Acad Sci USA. 2002;99(13):9055-60. 
11. Shani Z, Dekel M, Tsabary G, Goren R, Shoseyov O. Growth enhancement of transgenic poplar plants by overexpression of Arabidopsis thaliana endo-1,4-в-glucanase (ce/1). Mol Breed. 2004;14:321-30.

12. Park YW, Baba K, Furutab Y, lidab I, Sameshimac K, Araid M, Hayashi T. Enhancement of growth and cellulose accumulation by overexpression of xyloglucanase in poplar. FEBS Letters. 2004;564:183-7.

13. Funahashi F, Ohta S, Taniguchi T, Kurita M, Konagaya K, Hayashi T. Architectural and physiological characteristics related to the depressed growth of poplars overexpressing xyloglucanase in a field study. Trees. 2014;28(1):65-76.

14. Shestibratov KA, Podresov AS, Salmova MA, Kovalitskaya YA, Vidyagina EO, Miroshnikov Al, Loginov DS, Koroleva OV. Phenotypic manifestation of gene expression encoding xyloglucanase from Penicillium canescens in transgenic aspen plants. Russ J Plant Physiol. 2012;59(5):618-25.

15. Vidyagina EO, Kovalitskaya YA, Loginov DS, Koroleva OV, Shestibratov KA. Expression of xyloglucanase $s p$-Xeg gene from Penicillium canescens accelerates growth and rooting in transgenic aspen plants. Appl Biochem Microbiol. 2014;50(7):701-8.

16. Gallardo F, Fu J, Cantón FR, García-Gutiérrez A, Cánovas FM, Kirby EG. Expression of a conifer glutamine synthetase gene in transgenic poplar. Planta. 1999;210:19-26.

17. Jing ZP, Gallardo F, Pascual MB, Sampalo R, Romero J, Navarra AT, Cánovas FM. Improved growth in a field trial of transgenic hybrid poplar overexpressing glutamine synthetase. New Phytol. 2004; 164:137-45.

18. Castro-Rodríguez V, García-Gutiérrez A, Canales J, Cañas RA, Kirby EG, Avila C, Cánovas FM. Poplar trees for phytoremediation of high levels of nitrate and applications in bioenergy. Plant Biotechnol J. 2016;14:299-312.

19. Secchi F, Zwieniecki MA. The physiological response of Populus tremula $x$ alba leaves to the downregulation of PIP1 aquaporin gene expression under no water stress. Front Plant Sci. 2013;13(4):50716.

20. Secchi F, Zwieniecki MA. Down-regulation of plasma intrinsic protein1 aquaporin in poplar trees is detrimental to recovery from embolism. Plant Physiol. 2014;164(4):1789-99.

21. Behnke K, Ehlting B, Teuber M, Bauerfeind M, Louis S, Hänsch R, Polle A, Bohlmann J, Schnitzler JP. Transgenic, non-isoprene emitting poplars don't like it hot. The Plant J. 2007;51:485-99.

22. Behnke K, Kleist E, Uerlings R, Wildt J, Rennenberg H, Schnitzler JP. RNAi-mediated suppression of isoprene biosynthesis in hybrid poplar impacts ozone tolerance. Tree Physiol. 2009;29(5):725-36.

23. Park YW, Tominaga R, Sugiyama J, Furuta Y, Tanimoto E, Samejima M, Sakai F, Hayashi T. Enhancement of growth by expression of poplar cellulase in Arabidopsis thaliana. Plant $\mathrm{J}$. 2003;33(6):1099-106.

24. Jin YL, Tang RJ, Wang HH, Jiang CM, Bao Y, Yang Y, Liang MX, Sun ZC, Kong FJ, Li B, Zhang HX. Overexpression of Populus trichocarpa CYP85A3 promotes growth and biomass production in transgenic tree Plant Biotechnol J. 2017;15(10):1309-21.

25. Taniguchi T, Ohmiya Y, Kurita M, Tsubomura M, Kondo T, Park YW, Baba K, Hayashi T. Biosafety assessment of transgenic poplars overexpressing xyloglucanase (AaXEG2) prior to field trials. $J$ 
Wood Sci. 2008;54(5):408-13.

26. Busov VB, Brunner AM, Strauss SH. Genes for control of plant stature and form. New Phytol. 2008;177(3):589-607.

27. Gonzalez N, Bodt SD, Sulpice R, Jikumaru Y, Chae E, Dhondt S, Daele TV, Milde LD, Weigel D, Kamiya Y, Stitt M, Beemster GTS, Inzé D. Increased leaf size: different means to an end. Plant Physiol. 2010;153:1261-79.

28. Kim G-T, Tsukaya H, Saito Y, Uchimiya H. Changes in the shapes of leaves and flowers upon overexpression of cytochrome P450 in Arabidopsis. Proc Natl Acad Sci USA. 1999;96:9433-7.

29. Horiguchi G, Ferjani A, Fujikura U, Tsukaya H. Coordination of cell proliferation and cell expansion in the control of leaf size in Arabidopsis thaliana. J Plant Res. 2006;59(3):499-508.

30. Hayashi T, Kaida R. Functions of xyloglucan in plant cells. Mol Plant. 2011;4(1):17-24.

31. Saura-Valls M, Faure R, Brumer H, Teeri TT, Cottaz S, Driguez H, Planas A. Active-site mapping of a Populus xyloglucan endo-transglycosylase with a library of xylogluco-oligosaccharides. J Biol Chem. 2008;283(32):21853-63.

32. Baba K, Park YW, Kaku T, Kaida R, Takeuchi M, Yoshida M, Hosoo Y, Ojio Y, Okuyama T, Taniguchi T, Ohmiya Y, Kondo T, Shani Z, Shoseyov O, Awano T, Serada S, Norioka N, Norioka S, Hayashi T. Xyloglucan for generating tensile stress to bend tree stem. Mol Plant. 2009;2(5):893-903.

33. Biswal AK, Hao Z, Pattathil S, Yang X, Winkeler K, Collins C, Mohanty SS, Richardson EA, GelineoAlbersheim I, Hunt K, Ryno D, Sykes RW, Turner GB, Ziebell A, Gjersing E, Lukowitz W, Davis MF, Decker SR, Hahn M.G, Mohnen D. Downregulation of GAUT12 in Populus deltoids by RNA silencing results in reduced recalcitrance, increased growth and reduced xylan and pectin in a woody biofuel feedstock. Biotechnol Biofuels. 2015;8:41.

34. Yu L, Chen H, Sun J, Li L. PtrKOR1 is required for secondary cell wall cellulose biosynthesis in Populus. Tree Physiol. 2014;34(11):1289-300.

35. Bourquin V, Nishikubo N, Abe H, Brumer H, Denman S, Eklund M, Christiernin M, Teeri TT, Sundberg B, Mellerowicz EJ. Xyloglucan endotransglycosylases have a function during the formation of secondary cell walls of vascular tissues. Plant Cell. 2002;14:3073-88.

36. Ageeva MV, Amenitsky SI, Gorshkova TA, Guryanov OP, Ibragimova NN, Mikshina PV, Mokshina NE, Salnikov VV, Snegeryova AV, Chemikosova SB, Chernova TE. Biogenesis of plant fibers. Kazan Institute of Biochemistry and Biophesics, Kazan Science Centre, Russian Academy of Science, Kazan, Russian Federation. 2009;6-264.

37. Lebedev VG, Vidyagina EO, Larionova AA, Shestibratov KA. Decomposition of leaves, stems and roots of transgenic aspen with the xyloglucanase ( $s p-X e g)$ gene under laboratory microcosm conditions. Environments. 2017;4(1):4.

38. Becker ME. Microbial bioconversion of plant raw materials and prospects for its use. Vestnik AN USSR. 1983;6:1-6. 
39. Yang C, Schaefer DA, Liu W, Popescu VD, Yang C, Wang X, Wu C, Yu Higher fungal diversity is correlated with lower $\mathrm{CO}_{2}$ emissions from dead wood in a natural forest. Sci Rep. 2016;6:31066.

40. Zhang D, Hui D, Luo Y, Zhou G. Rates of litter decomposition in terrestrial ecosystems: global patterns and controlling factors. J Plant Ecol. 2008;1(2):85-93.

41. Freschet GT, Aerts R, Cornelissen JHC. A plant economics spectrum of litter decomposability. Funct Ecol. 2012; 26(1):56-65.

42. Weedon, JT, Cornwell WK, Cornelissen JHC, Zanne AE, Wirth C, Coomes DA. Global meta-analysis of wood decomposition rates: a role for trait variation among tree species? Ecology Letters. 2009;12(1):45-56.

43. Kvitkina AK, Larionova AA, Bykhovets SS. Effect of exogenous and endogenous nitrogen on the rate of mineralization of plant remains of maize. Agrochemistry. 2014;9:48-57.

44. Geffen KG, Poorter L, Sass-Klaassen U, Logtestijn RS, Cornelissen JH. The trait contribution to wood decomposition rates of 15 Neotropical tree species. Ecology. 2010;91(12):3686-97.

45. Komarov AS, Chertov OG, Bykhovets SS, Priputina IV, Shanin VN, Vidjagina EO, Lebedev VG, Shestibratov KA. Effects of the aspen short-rotation plantation on the $C$ and $N$ biological cycles in boreal forests: the model experiment. Math Biol Bioinf. 2015;10(2):398-415.

46. Axelsson EP, Hjältén J, LeRoy CJ. Performance of insect-resistant Bacillus thuringiensis (Bt)expressing aspens under semi-natural field conditions including natural herbivory in Sweden. For. Ecol. Manag. 2012;264:167-71.

47. Castro-Rodriguez V, Garcia-Gutierrez A, Canales J, Avila C, Kirby EG, Canovas FM. The glutamine synthetase gene family in Populus. BMC Plant Biol. 2011;11:119.

48. Laemmli UK. Cleavage of structural proteins during the assembly of the head of bacteriophage T4. Nature. 1970;227:680-5.

49. Bylesjö M, Segura V, Soolanayakanahally RY, Rae AM, Trygg J, Gustafsson P, Jansson S, Street NR. LAMINA: a tool for rapid quantification of leaf size and shape parameters. BMC Plant Biol. 2008;8:82.

50. Kurschner K, Hanak A. Determination of cellulose. Z. utersuch. Lebensm. 1930;59:448-85.

51. Obolenskaya AV, Elnitskaya ZP, Leonovich AA. Laboratory work on the chemistry of wood. Moscow, Ekologiya, 1991. 320 p.

52. Wilson WK, Mandel J. Determination of pentosans. Tappi J. 1960;43(12):998.

53. Foster CE, Martin TM, Pauly M. Comprehensive compositional analysis of plant cell walls (lignocellulosic biomass). Part II: carbohydrates. J Vis Exp. 2010;37(e1837):1-4.

54. Cai Y, Zhang K, Kim H, Hou G, Zhang X, Yang H, Feng H, Miller L, Ralph J, Liu CJ. Enhancing digestibility and ethanol yield of Populus wood via expression of an engineered monolignol 4-0methyltransferase. Nat Commun. 2016;7(11989):1-14.

55. York WS, Darvill AG, McNeil M, Stevenson TT, Albersheim P. Isolation and characterization of plant cell walls and cell wall components. Meth Enzymol. 1986;118:3-40. 
56. Lockwood WR. A reliable and easily sectioned epoxy embedding medium. Anat Rec. 1964;150:12940.

57. Humphrey CD, Pittman FE. A simple methylene blue - asure II - basic fuchsin stain for epoxyembedding tissue sections. Stain Technol. 1974;49(1):9-14.

58. Spearin WE, Isenberg IH. The maceration of woody tissue with acetic acid and sodium chlorite. Science. 1947;105(2721):214.

59. Kuznetsova TV, Tulina AS, Semenov VM, Kudeyarov VN. On the conjugate processes of the metabolism of carbon and nitrogen in the soil. Eurasian Soil Sci. 1998;7:832-9.

\section{Tables}

Table 1 Growth rate indicators, number of leaves and cellulose content ( \pm SD) in the 18month-old aspen transgenic and control lines in semi-natural conditions

\begin{tabular}{cccccc}
\hline Line & Height, $\mathrm{cm}$ & $\begin{array}{c}\text { Stem diameter, } \\
\mathrm{mm}\end{array}$ & $\begin{array}{c}\text { Volume, } \\
\mathrm{cm}^{3}\end{array}$ & $\begin{array}{c}\text { Number of } \\
\text { leaves }\end{array}$ & $\begin{array}{c}\text { Cellulose content, } \\
\mathrm{mg} / \mathrm{g}\end{array}$ \\
\hline Pt (control) & $59.4 \pm$ & $6.6 \pm 0.22$ & $\begin{array}{c}25.8 \pm \\
0.95\end{array}$ & $24.2 \pm 0.84$ & $383.2 \pm 10.97$ \\
& 1.97 & & $25.8 \pm$ & $26.2 \pm 1.05$ & $381.2 \pm 12.33$ \\
PtXIVXeg1a & $61.1 \pm$ & $6.5 \pm 0.15$ & 0.78 & & \\
& 2.14 & & $20.5 \pm 1.0$ & $25.3 \pm 0.88$ & $397.6 \pm 11.52$ \\
PtXIVXeg1b & $53.3 \pm$ & $6.2 \pm 0.23$ & & \\
& 1.91 & & $28.2 \pm$ & $25.1 \pm 0.90$ & $426.4 \pm 12.39 *$ \\
PtXIVXeg1c & $59.3 \pm$ & $6.9 \pm 0.2$ & 0.93 & \\
& 2.34 & & $43,4 \pm$ & $29.4 \pm 0.99 *$ & $411.3 \pm 11.57 *$ \\
PtXVXeg1b & $69.6 \pm$ & $7.9 \pm 0.23 *$ & $1.04 *$ \\
& $2.67 *$ & & & \\
PtXVXeg3b & $51.2 \pm$ & $6.5 \pm 0.16$ & $21.63 \pm$ & $25.2 \pm 0.82$ & $388.7 \pm 11.44$ \\
& 1.85 & & 0.87 & \\
\hline PtXVXeg5a & $60.5 \pm$ & $6.1 \pm 0.22$ & $22.51 \pm$ & $25.0 \pm 1.07$ & $379.6 \pm 10.86$ \\
& 2.02 & & 0.98 & \\
\hline
\end{tabular}

*significantly different from $P t$ at $P \leq 0.05$ based on ANOVA

Table 2 Leaf trait parameters ( \pm SD) of the 18-month-old aspen lines 


\begin{tabular}{cccccc}
\hline Line & Area, $\mathrm{mm}^{2}$ & Circularity & Length, $\mathrm{mm}$ & Width, $\mathrm{mm}$ & $\begin{array}{c}\text { Length to } \\
\text { width }\end{array}$ \\
\hline Pt(control) & $5776.3 \pm 203.9$ & $91.6 \pm 1.79$ & $96.3 \pm 2.85$ & $81.0 \pm 2.51$ & $1.20 \pm 0.04$ \\
PtXIVXeg1a & $4921.6 \pm 172.2$ & $85.5 \pm$ & $100.1 \pm 3.09$ & $69.1 \pm$ & $1.47 \pm 0.05^{*}$ \\
& & $1.91^{*}$ & & $2.03^{*}$ & \\
PtXIVXeg1b & $4176.3 \pm$ & $86.0 \pm$ & $89.9 \pm 2.77$ & $65.3 \pm$ & $1.39 \pm 0.04^{*}$ \\
& $156.7^{*}$ & $1.85^{*}$ & & $2.59^{*}$ & \\
PtXIVXeg1c & $5526.3 \pm 197.8$ & $87.1 \pm$ & $102.4 \pm 2.35$ & $75.0 \pm 2.77$ & $1.38 \pm 0.04^{*}$ \\
& & $1.09^{*}$ & & & \\
PtXVXeg1b & $6020.8 \pm 210.7$ & $90.1 \pm 2.14$ & $105.1 \pm 2.71$ & $77.7 \pm 2.56$ & $1.37 \pm 0.04^{*}$ \\
PtXVXeg3b & $4784.6 \pm$ & $88.2 \pm$ & $95.5 \pm 1.98$ & $68.9 \pm$ & $1.39 \pm 0.05^{*}$ \\
& $167.4^{*}$ & $1.15^{*}$ & & $2.09^{*}$ & \\
PtXVXeg5a & $5901.5 \pm 212.4$ & $86.6 \pm$ & $108.8 \pm$ & $76.2 \pm 2.45$ & $1.45 \pm 0.05^{*}$ \\
& & $1.55^{*}$ & $2.79 *$ & & \\
\hline
\end{tabular}

*significantly different from $P t$ at $P \leq 0.05$ based on ANOVA

Table 3 The percentage of pentosans ( \pm SD) in different parts of the 18-month-old aspen lines

Line Wood of the 6 month of cultivation Wood of the 18 month of cultivation

\begin{tabular}{ccc}
\hline Pt & $23.1 \pm 0.57$ & $18.8 \pm 0.56$ \\
PtXIVXeg1a & $17.5 \pm 0.53^{*}$ & $17.8 \pm 0.48$ \\
PtXIVXeg1b & $20.8 \pm 0.46$ & $20.7 \pm 0.60$ \\
PtXIVXeg1c & $21.8 \pm 0.94$ & $20.3 \pm 0.58$ \\
PtXVXeg1b & $21.5 \pm 0.53$ & $17.9 \pm 0.50$ \\
PtXVXeg3b & $21.3 \pm 0.76$ & $19.8 \pm 0.55$ \\
PtXVXeg5a & $23.0 \pm 0.61$ & $22.2 \pm 0.61$ \\
\hline
\end{tabular}

* significantly different from $P t$ at $P \leq 0.05$ based on ANOVA

Table 4 Mean diameter and length ( \pm SD) of wood fiber in aspen lines 


\begin{tabular}{ccc}
\hline Line & Mean diameter, $m k m$ & Mean length, $m k m$ \\
\hline Pt (control) & $19.58 \pm 1.84$ & $488.9 \pm 12.7$ \\
PtXIVXeg1a & $20.14 \pm 1.80$ & $506.7 \pm 14.3^{*}$ \\
PtXIVXeg1b & $19.76 \pm 1.61$ & $487.6 \pm 11.6$ \\
PtXIVXeg1c & $20.16 \pm 1.27$ & $461.8 \pm 17.4$ \\
PtXVXeg1b & $20.01 \pm 1.93$ & $512.0 \pm 10.8^{*}$ \\
PtXVXeg3b & $19.57 \pm 1.54$ & $524.3 \pm 13.0^{*}$ \\
PtXVXeg5a & $21.98 \pm 1.93$ & $487.8 \pm 15.2$ \\
\hline
\end{tabular}

* significantly different from $P t$ at $P \leq 0.05$ based on ANOVA

Table 5 Percentage of nitrogen and carbon $( \pm$ SD) in the wood of the aspen lines

\begin{tabular}{ccccc}
\hline \multirow{2}{*}{ Line } & \multicolumn{2}{c}{ Stems } & \multicolumn{2}{c}{ Roots } \\
\cline { 2 - 5 } & nitrogen & carbon & nitrogen & carbon \\
\hline Pt & $1.23 \pm 0.12$ & $45.8 \pm 1.5$ & $1.7 \pm 0.3$ & $45.5 \pm 1.5$ \\
PtXIVXeg1b & $1.04 \pm 0.19^{*}$ & $46.1 \pm 1.5$ & $1.9 \pm 0.4$ & $45.5 \pm 1.5$ \\
\hline PtXVXeg3b & $1.05 \pm 0.18^{*}$ & $45.9 \pm 1.5$ & $1.8 \pm 0.3$ & $44.9 \pm 1.4$ \\
\hline
\end{tabular}

* significantly different from $P t$ at $P \leq 0.05$ based on ANOVA

\section{Figures}

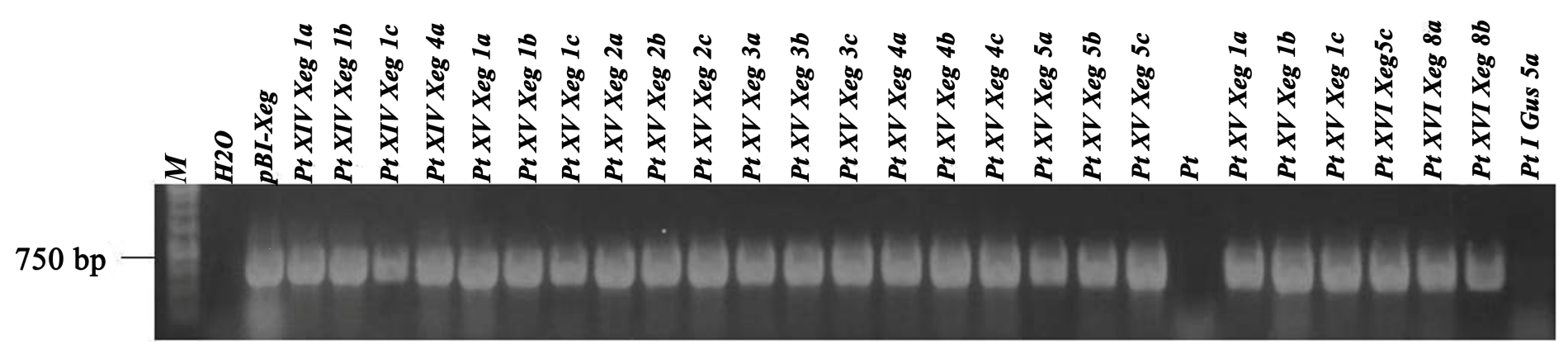

Figure 1

RT-PCR analysis of the sp-Xeg gene expression in transgenic aspen plants (expected amplicon size 762 bp). M - standard molecular marker $1 \mathrm{~kb}$ (SibEnzyme), $\mathrm{H} 2 \mathrm{O}$ - negative reaction control, pBI-Xeg - plasmid DNA (positive control), Pt - non-transgenic control line, PtIGus5a - transgenic control line (uncropped image of the gel is available from the corresponding author upon request). 


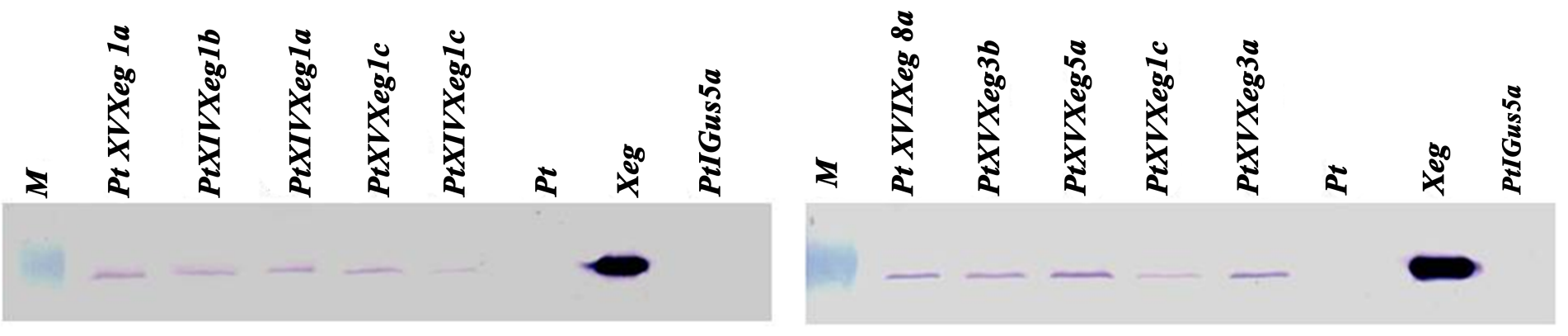

Figure 2

Western blot analysis of protein extracts of transgenic aspens carrying the recombinant gene sp-Xeg. M standard protein molecular marker $26 \mathrm{kDa}$, Xeg - fungal extract, Pt - non-transgenic control, PtIGus5a transgenic negative control, PtXIVXeg1a, PtXIVXeg1b, PtXIVXeg1c, PtXVXeg1a, PtXVXeg1b, PtXVXeg1c, PtXVXeg3a, PtXVXeg3b, PtXVXeg5a, and PtXVIXeg8a are transgenic lines (uncropped image of the gel is available from the corresponding author upon request)
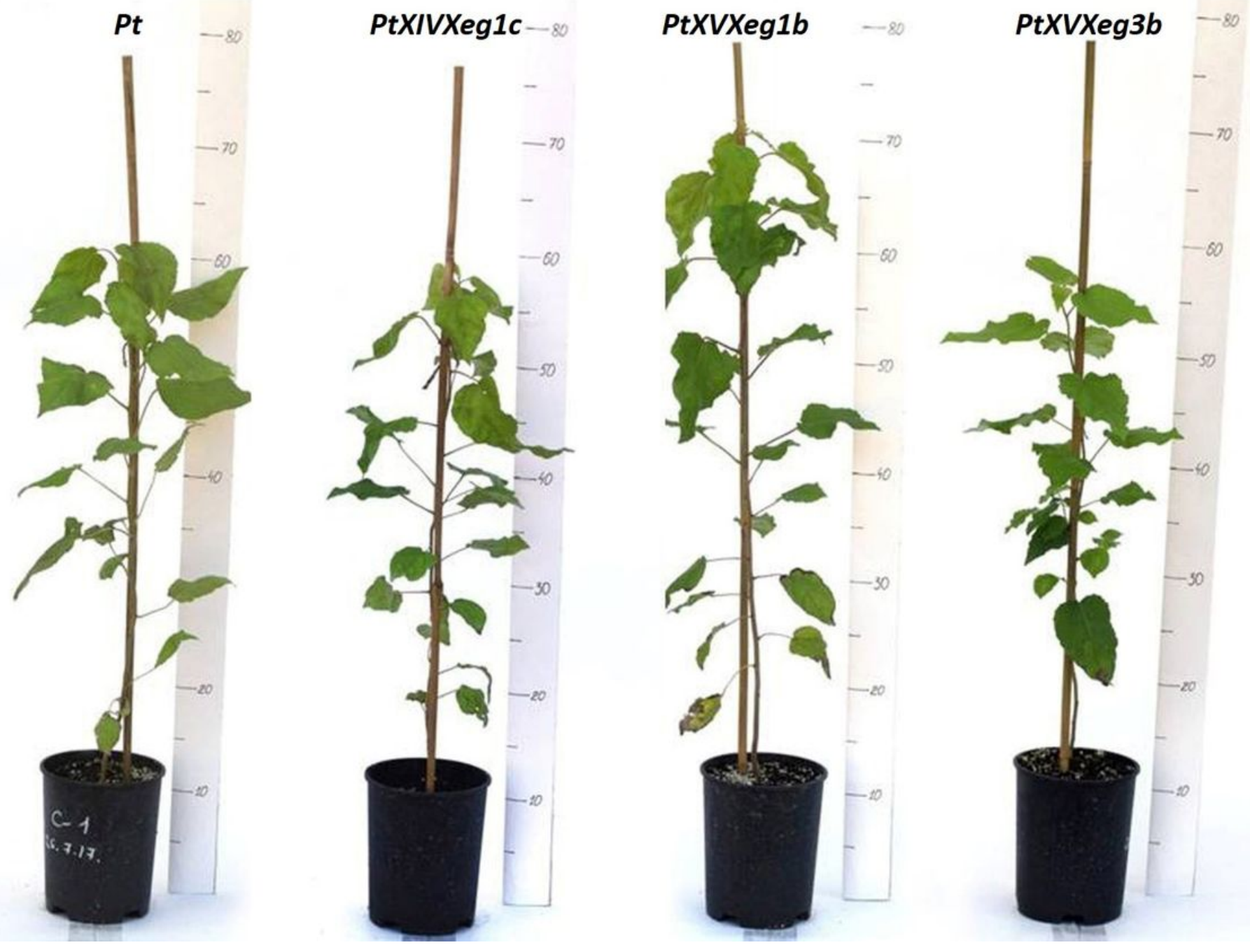

Figure 3 
Samples of the 18-month-old aspen plants of high and low growth transgenic lines (PtXIVXeg1c, PtXVXeg1b, and PtXVXeg3b) and non-transformed control (Pt) from semi-natural conditions

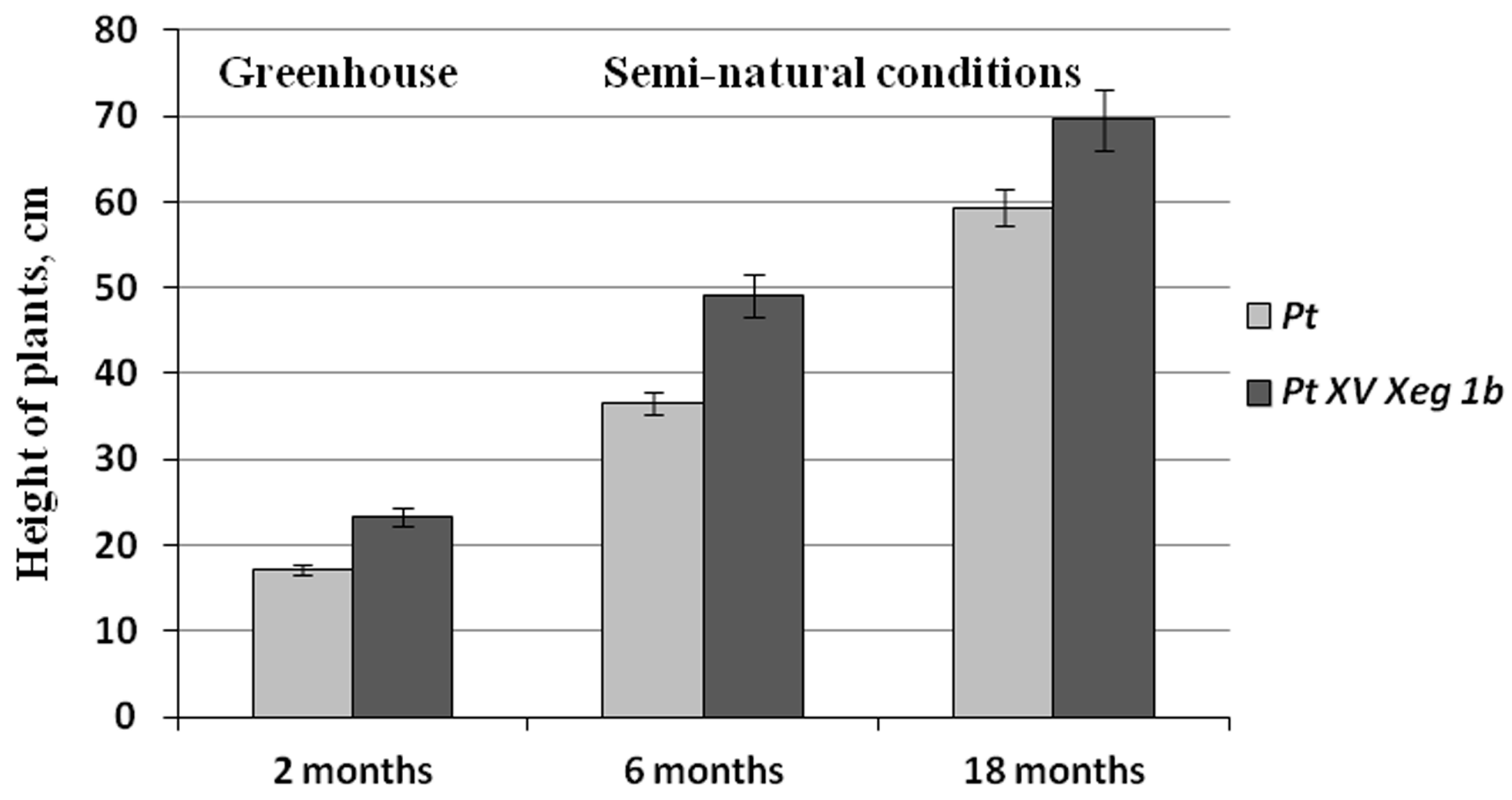

Figure 4

Growth rate of the transgenic (PtXVXeg1b) and non-transgenic (Pt control) aspen lines
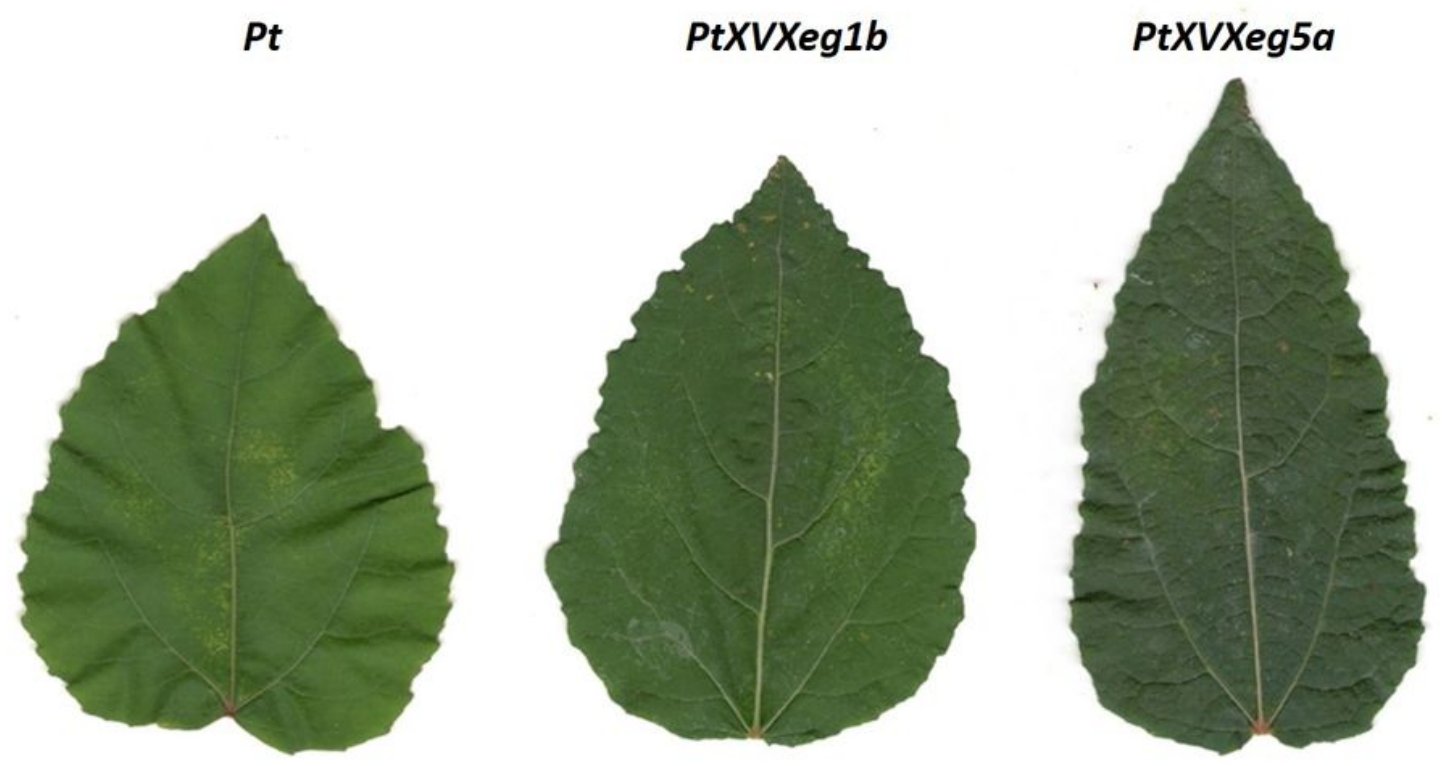

PtXVXeg3b

Figure 5 
Aspen leaves under semi-natural conditions presenting control $(\mathrm{Pt})$ and transgenic lines PtXVXeg1b (demonstrating a statistically significant changed the length-to-width ratio of the leaf), PtXVXeg5a (demonstrating a statistically significant increase in the length of the main vein), and PtXVXeg3b (demonstrating a statistically significant decrease in the leaf blade area)

a

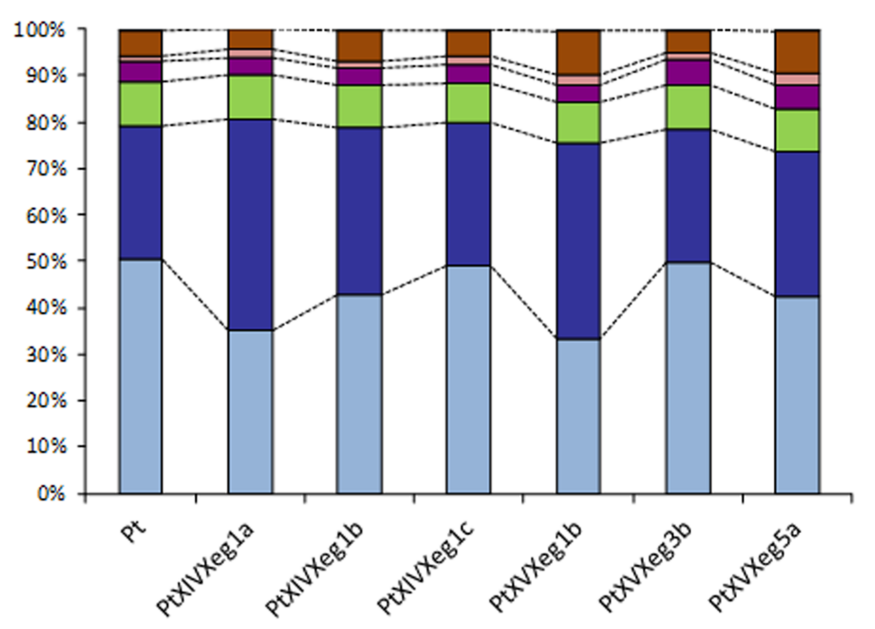

b

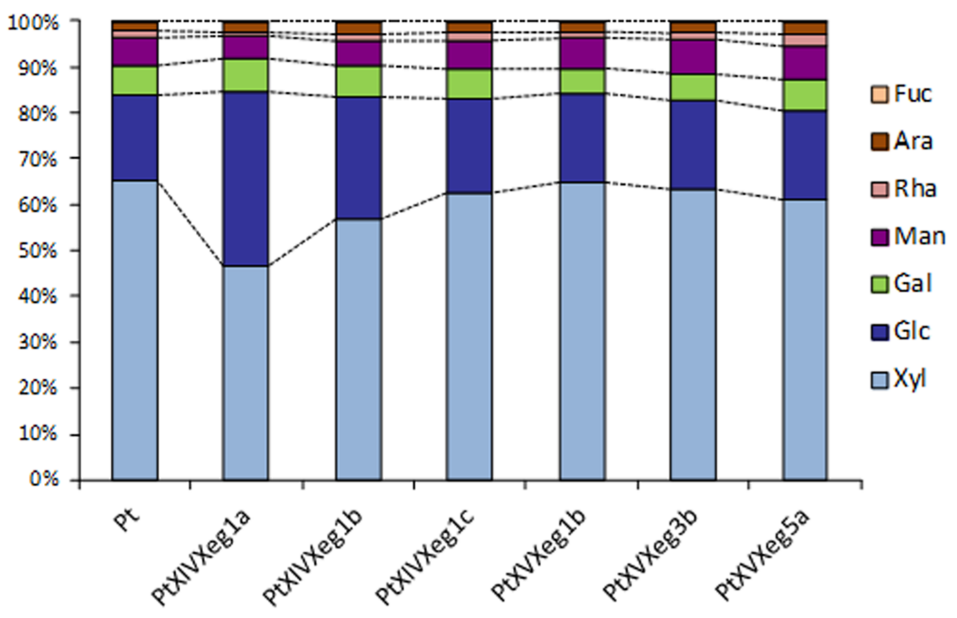

Figure 6

Monomeric sugars composition in wood of the 6- (a) and 18-(b) month-old aspen lines. Fuc - fucose, Ara - arabinos, Rha - rhamnose, Man - mannose, Gal - galactose, Glc - glucose, Xyl - xylose 


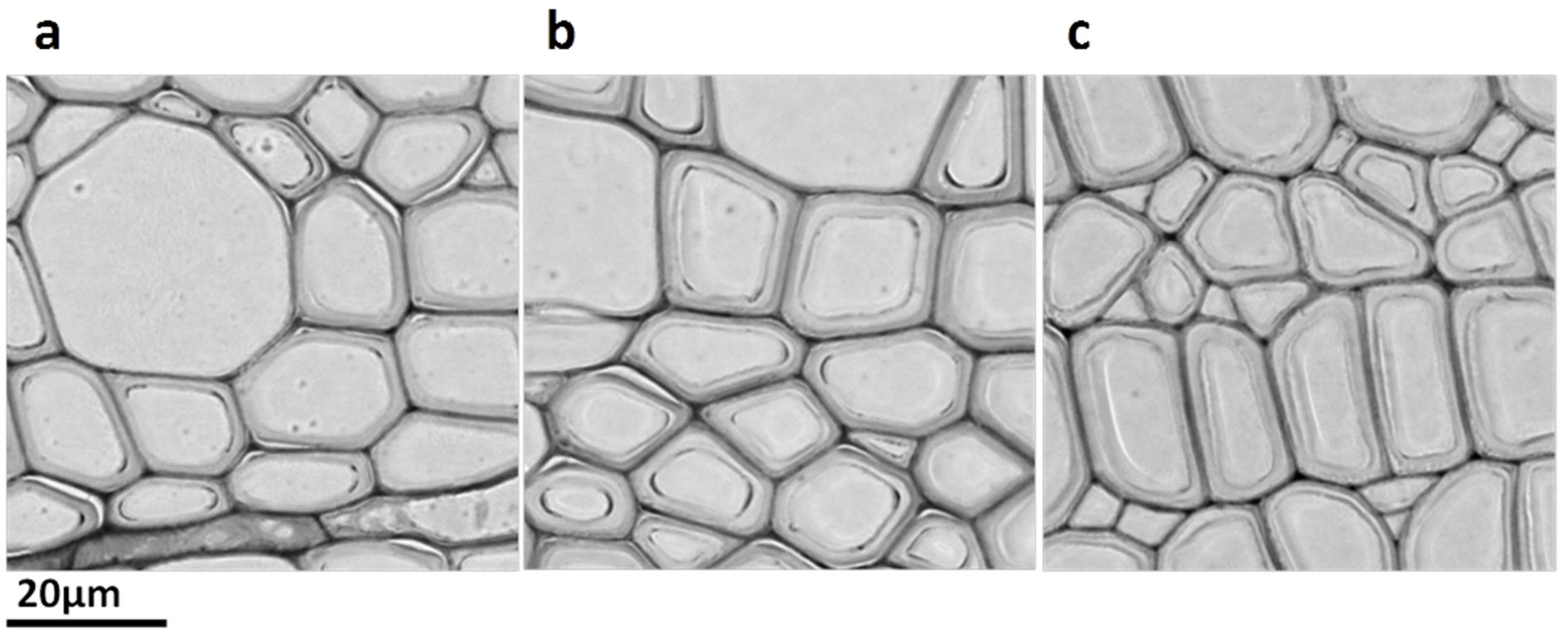

Figure 7

Micrograph of cell slices of plant xylem with different cell wall thickness of $1.16 \pm 0.044$ microns in control line Pt (a) and $1.47 \pm 0.045$ and $1.80 \pm 0.056$ in transgenic lines PtXIVXeg1c (b) and PtXVXeg1b (c), respectively
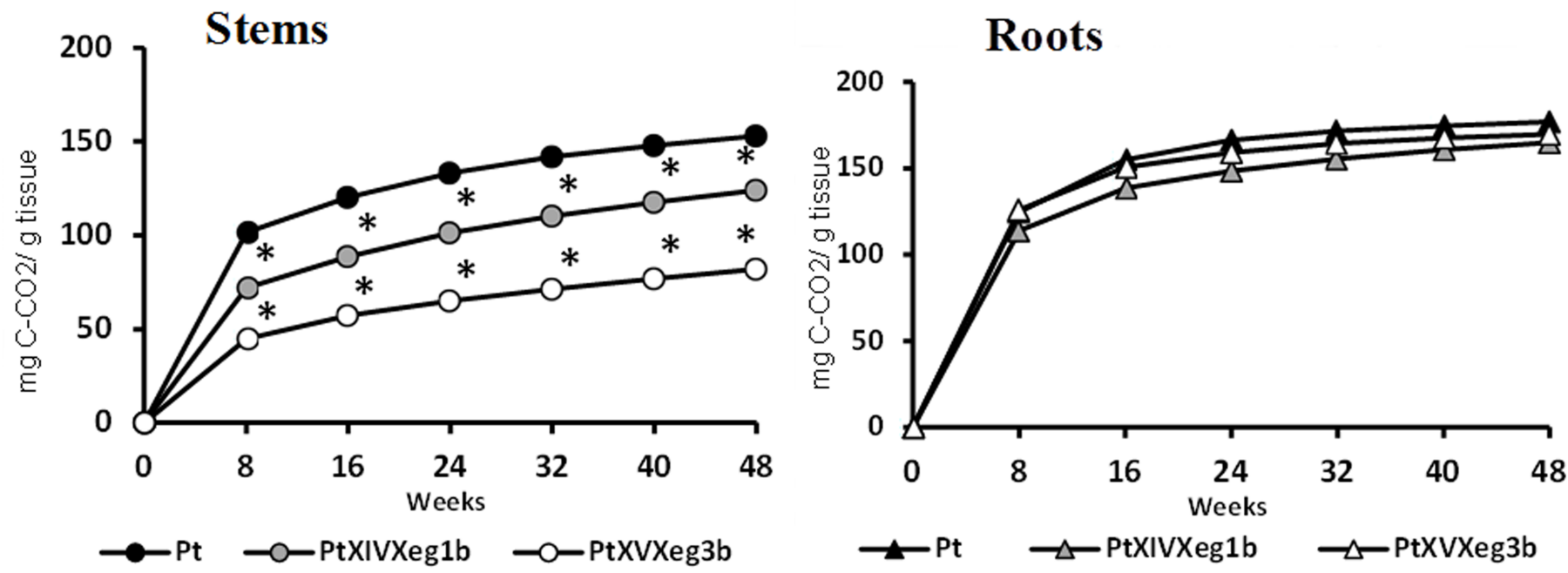

Figure 8 
Cumulative $\mathrm{CO} 2$ emissions during decomposition of stems and roots of transgenic (PtXIVXeg1 $\mathrm{b}$ and $\mathrm{PtXVXeg} 3 \mathrm{~b})$ and control $(\mathrm{Pt})$ aspens during the year; *statistically significantly different from $\mathrm{Pt}$ at $\mathrm{P} \leq$ 0.05 based on ANOVA

\section{Supplementary Files}

This is a list of supplementary files associated with this preprint. Click to download.

- Fig21uncroppedBW.jpg

- Fig1uncroppedBW.png

- eq3.jpg

- eq1.jpg

- Fig22uncroppedBW.jpg

- eq2.jpg

- Fig1uncroppedcolor.png 